Vietnam Journal of Mechanics, VAST, Vol.30, No. 1 (2008), pp. 20-32

\title{
POTENTIAL EVAPOTRANSPIRATION ESTIMATION AND ITS EFFECT ON HYDROLOGICAL MODEL RESPONSE
}

\author{
Vu Van Nghi $^{1}$ \\ State Key Laboratory of Hydrology, \\ Water Resources and Hydraulic Engineering, \\ Hohai University, no. 1 Xikang Road, Nanjing 210098, China \\ Do Duc Dung, Dang Thanh Lam \\ Southern Institute for Water Resources Planning, \\ 271/3 An Duong Vuong Street, District 5, \\ Ho Chi Minh City, Vietnam
}

\begin{abstract}
Potential evapotranspiration can be directly calculated by the Penman-Monteith equation, known as the one-step method. The approach requires data on the land cover and related-vegetation parameters based on AVHRR and LDAS information, which are available in recent years. The Nong Son basin, a sub-catchment of the Vu Gia-Thu Bon basin in the Central Vietnam, is selected for this study. To this end, NAM model was used; the results obtained show that the NAM model has the potential to reproduce the effects of potential evapotranspiration on hydrological response. This is seemingly manifested in the good agreement between model simulation of discharge and the observed at the stream gauge.

Keywords: Potential evapotranspiration, Penman-Monteith method, Piche evaporation, Leaf area index (LAI), Normalized difference vegetation index (NDVI)
\end{abstract}

\section{INTRODUCTION}

One of the key inputs to hydrological modeling is potential evapotranspiration, which refers to maximum meteorologically evaporative power on land surface. Two kinds of potential evapotranspiration are necessary to be defined: either from the interception or from the root zone when the interception is exhausted but soil water is freely available, specifically at field capacity (see [10], [32]). The actual evapotranspiration is distinguished from the potential through the limitations imposed by the water deficit. Evapotranspiration can be directly measured by lysimeters or eddy correlation method but expensively and practically only in research over a plot for a short time. The pan or Piche evaporation has long records with dense measurement sites. To apply it in hydrological models, however, first, a pan/Piche coefficient, $K_{p}$, then a crop coefficient, $K_{c}$, must be multiplied as well. Due to the difference on sitting and weather conditions, $K_{p}$ is often expressed as a function of local environmental variables such as wind speed, humidity, upwind fetch, etc. A global equation of $K_{p}$ is still lack. The values of $K_{c}$ from the literature are empirical, most for agricultural crops, and subjectively selected. Moreover, the observed Piche data show

${ }^{1}$ Corresponding author:

Email: vuvannghi@yahoo.com Tel: 0086.15850569677 
some erroneous results which are difficult to explain (see [22]), and the pan evaporameter is not considered accurate (see [7], [8]). On the other hand, a great number of evaporation models has been developed and validated, from the single climatic variable driven equations (see [29]) to the energy balance and aerodynamic principle combination methods (see [23]). Among them, probably the Penman equation is the most physically sound and rigorous. Monteith (see [19]) generalized the Penman equation for water-stressed crops by introducing a canopy resistance. Now the Penman-Monteith model is widely employed.

As a result, in this study the Penman-Monteith method is selected to compute directly potential evapotranspiration according to the vegetation dataset at 30 s resolution based on AVHRR (Advanced Very High Resolution Radiometer) and LDAS (Land Data Assimilation System) information for the Nong Son catchment. To assess the suitability of this approach, the conceptual rainfall-runoff model known as NAM (see [9]) is used to examine its effect on hydrological response.

\section{POTENTIAL EVAPOTRANSPIRATION MODEL DESCRIPTION}

\subsection{Penman-Monteith equation}

Potential evapotranspiration can be calculated directly with the Penman-Monteith equation (see [3]) as follows:

$$
\lambda E T=\frac{\Delta\left(R_{n}-G\right)+\rho_{a} c_{p} \frac{\left(e_{s}-e_{a}\right)}{r_{a}}}{\Delta+\gamma\left(1+\frac{r_{s}}{r_{a}}\right)},
$$

where $E T$ is the evapotranspiration rate $\left(\mathrm{mm} \cdot \mathrm{d}^{-1}\right) ; \lambda$ is the latent heat of vaporization (=

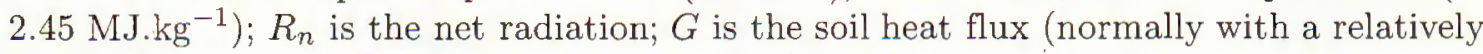
small value, in general, it may be ignored (see [3])); $e_{s}$ is the saturated vapor pressure; $e_{a}$ is the actual vapor pressure; $\left(e_{s}-e_{a}\right)$ represents the vapour pressure deficit of the air; $\rho_{a}$ is the mean air density at constant pressure; $c_{p}$ is the specific heat of the air $\left(=1.01 \mathrm{~kJ} \mathrm{~kg}^{-1} \mathrm{~K}^{-1}\right)$; $\Delta$ represents the slope of the saturation vapour pressure temperature relationship; $\gamma$ is the psychrometric constant; and $r_{s}$ and $r_{a}$ are the (bulk) surface and aerodynamic resistances.

The Penman-Monteith approach as formulated above includes all parameters that govern energy exchange and corresponding latent heat flux (evapotranspiration) from uniform expanses of vegetation. Most of the parameters are measured or can be readily calculated from weather data. The equation can be utilized for the direct calculation of any crop evapotranspiration as the surface and aerodynamic resistances are crop specific.

\subsection{Factors and parameters determining ET}

\subsubsection{Land surface resistance parameterization}

\section{a. Aerodynamic resistance}

The rate of water vapor transfer away from the ground by atmospheric turbulent diffusion is controlled by aerodynamic resistance $r_{a}\left(\mathrm{~s} \cdot \mathrm{m}^{-1}\right)$, which is inversely proportional to wind speed and changes with the height of the vegetation covering the ground, as

$$
r_{a}=\frac{\ln \left[\left(z_{u}-d\right) / z_{o m}\right] \ln \left[\left(z_{e}-d\right) / z_{o h}\right]}{\kappa^{2} u_{z}},
$$


where $z_{u}$ is the height of wind measurements $(\mathrm{m}) ; z_{e}$ is the height of humidity measurements $(\mathrm{m}) ; d$ is the zero plane displacement height $(\mathrm{m}) ; z_{o m}$ is the roughness length governing momentum transfer $(\mathrm{m})$; $z_{\text {oh }}$ is the roughness length governing transfer of heat and vapour $(\mathrm{m}) ; u_{z}$ is the wind speed; and $\kappa$ is the von-Karman constant $(=0.41)$.

Many studies have explored the nature of the wind regime in plant canopies. $d$ and $z_{\text {om }}$ have to be considered when the surface is covered by vegetation. The factors depend upon the crop height and architecture. Several empirical equations (see [5], [11], [20], [31]) for the estimate of $d, z_{o m}$ and $z_{o h}$ have been developed. In this study, estimate can be made of $r_{a}$ by assuming (see [4]) that $z_{o m}=0.123 h_{c}$ and $z_{o h}=0.0123 h_{c}$, and (see [20]) that $d=0.67 h_{c}$, where $h_{c}(\mathrm{~m})$ is the mean height of the crop.

b. Surface resistance

The 'bulk' surface resistance $r_{s}\left(\mathrm{~s} \cdot \mathrm{m}^{-1}\right)$ describes the resistance of vapour flow through the transpiring crop and evaporating soil surface. Where the vegetation doesn't completely cover the soil, the resistance factor should indeed include the effects of the evaporation from the soil surface. If the crop isn't transpiring at a potential rate, the resistance depends also on the water status of the vegetation. An acceptable approximation (see [1], [3]) to a much more complex relation of the surface resistance of fully dense cover vegetation is:

$$
r_{s}=\frac{r_{l}}{L A I_{\text {active }}},
$$

where $r_{l}$ is the bulk stomatal resistance of the well-illuminated $\left(\mathrm{s} . \mathrm{m}^{-1}\right)$; and $L A I_{\text {active }}$ is the active (sunlit) leaf area index $\left(\mathrm{m}^{2}\right.$ leaf area over $\mathrm{m}^{2}$ soil surface).

A general equation (see [2], [15], [30]) for $L A I_{\text {active }}$ is:

$$
L A I_{\text {active }}=0.5 L A I \text {. }
$$

The bulk stomatal resistance, $r_{l}$, is the average resistance of an individual leaf. This resistance is crop specific and differs among crop varieties and crop management. It usually increases as the crop ages and begins to ripen. There is, however, a lack of consolidated information on changes in $r_{l}$ over time for the different crops. The information available in the literature on stomatal resistance is often oriented toward physiological or ecophysiological studies. The stomatal resistance is influenced by climate and by water availability. However, the influences vary from one crop to another and different varieties can be affected differently. The resistance increases when the crop is water stressed and the soil water availability limits crop evapotranspiration. Some studies (see [13], [14], [18], [26], [33]) indicate that stomatal resistance is influenced to some extent by radiation intensity, temperature and vapour pressure deficit.

If the crop is amply supplied with water, the crop resistance, $r_{s}$, reaches a minimum value, known as the basis canopy resistance. The transpiration of the crop is then maximum and referred to as potential transpiration. The relation between $r_{s}$ and the pressure head in the root zone is crop dependent. Minimum values of $r_{s}$ range from $30 \mathrm{s.m}^{-1}$ for arable crops to $150 \mathrm{~s} . \mathrm{m}^{-1}$ for forest. For grass a value of $70 \mathrm{s.m} \mathrm{m}^{-1}$ is often used (see [7]). It should be noted that $r_{s}$ cannot be measured directly, but has to be derived from the PenmanMonteith formula where $E T$ is obtained from e.g. the water balance of a lysimeter.

The Leaf Area Index ( $L A I)$, a dimensionless quantity, is the leaf area (upper side only) per unit area of soil below it. The active $L A I$ is the index of the leaf area that actively contributes to the surface heat and vapour transfer. It is generally the upper, sunlit portion of a dense canopy. The $L A I$ values for various crops differ widely but values of $3-5$ are 
common for many mature crops. For a given crop, the green $L A I$ changes throughout the season and normally reaches its maximum before or at flowering. $L A I$ further depends on the plant density and the crop variety. Several studied and empirical equations (see [18], [31]) for the estimate of $L A I$ have been developed. If $h_{c}$ is the mean height of the crop, then the $L A I$ can be estimated (see [1]) by:

$$
\begin{array}{ll}
L A I=24 h_{c} & \text { (clipped grass with } \left.0.05<h_{c}<0.15 \mathrm{~m}\right) \\
L A I=5.5+1.5 \ln \left(h_{c}\right) & \text { (alfalfa with } \left.0.10<h_{c}<0.50 \mathrm{~m}\right)
\end{array}
$$

As an alternative, spectral vegetation indices from satellite-based spectral observations, such as $N D V I$ (normalized difference vegetation index), or simple ratio $(S R=(1$ $+N D V I) /(1-N D V I))$; are widely used to extract vegetation biophysical parameters of which $L A I$ is the most important. The use of monthly vegetation index is a good way to take into account the phenological development of the $L A I$, as well as the effects of prolonged water stresses that reduce the $L A I$ (see [17]). In this study, monthly maximum composite $1-\mathrm{km}$ resolution NDVI dataset obtained from NOAA-AVHRR (National Oceanic and Atmospheric Administration-Advanced very High Resolution Radiometer) in 1992, 1995 and 1996 were used to estimate $L A I$. The simple relationships between LAI and NDVI were taken from SiB2 (see [25]). For evenly distributed vegetation, such as grass and crops:

$$
L A I=L A I_{\max } \frac{\ln (1-F P A R)}{\ln \left(1-F P A R_{\max }\right)} .
$$

For clustered vegetation, such as coniferous trees and shrubs:

$$
L A I=\frac{L A I_{\max } F P A R}{F P A R_{\max }},
$$

where FPAR is the fraction of photosynthetically active radiation absorbed by the canopy, calculated as:

$$
F P A R=\frac{\left(S R-S R_{\min }\right)\left(F P A R_{\max }-F P A R_{\min }\right)}{S R_{\max }-S R_{\min }},
$$

where $F P A R_{\max }$ and $F P A R_{\min }$ are taken as 0.950 and 0.001 , respectively. $S R_{\max }$ and $S R_{\min }$ are $S R$ values corresponding to 98 and $5 \%$ of $N D V I$ population, respectively.

Land cover classes of needleleaf deciduous, evergreen and shrub land thicket are treated as clumped vegetation types (see [24]). In cases where there is a combination of clustered and evenly distributed vegetation, $L A I$ can be calculated by a combination of Equation (6) and (7):

$$
L A I=\left(1-F_{c l}\right) L A I_{\max } \frac{\ln (1-F P A R)}{\ln \left(1-F P A R_{\max }\right)}+F_{c l} \frac{L A I_{\max } F P A R}{F P A R_{\max }},
$$

where $F_{c l}$ is the fraction of clumped vegetation in the area.

2.2.2. Surface exchanges

a. Saturated vapor content of air

The saturated vapor pressure is related to temperature; if $e_{s}$ is in kilopascals $(\mathrm{kPa})$ and $T$ is in degrees Celsius $\left({ }^{\circ} \mathrm{C}\right)$, an approximate equation (see [28]) is:

$$
e_{s}=0.6108 \exp \left(\frac{17.27 T}{237.3+T}\right) \text {. }
$$


It is important in building physically based models of evaporation that not only is $e_{s}$ a known function of temperature, but also so is $\Delta\left(\mathrm{kPa}^{-1} \mathrm{C}^{-1}\right)$, the gradient of this function, $d e_{s} / d T$. This gradient is given by:

$$
\Delta=\frac{4098 e_{s}}{(237.3+T)^{2}} .
$$

The relative humidity ( $R H \%$ ) expresses the degree of saturation of the air as a ratio of the actual $\left(e_{a}\right)$ to the saturation $\left(e_{s}\right)$ vapour pressure at the same temperature $(T)$ :

$$
R H=100 \frac{e_{a}}{e_{s}} .
$$

b. Sensible heat

The density of (moist) air can be calculated from the ideal gas laws, but it is adequately estimated from:

$$
\rho_{a}=3.486 \frac{P}{275+\bar{T}}
$$

where $P$ is the atmospheric pressure in $\mathrm{kPa}$. Assuming $20^{\circ} \mathrm{C}$ for a standard atmosphere, $P$ as a function of height $z$ (in meters) above the mean sea level can be employed to calculate by:

$$
P=101.3 \times\left(\frac{293-0.0065 z}{293}\right)^{5.26} .
$$

c. Psychrometric constant

The psychrometric constant, $\gamma\left(\mathrm{kPa} .{ }^{\circ} \mathrm{C}^{-1}\right)$, is given by:

$$
\gamma=\frac{c_{p} P}{\varepsilon \lambda}=0.665 \times 10^{-3} P
$$

where $\varepsilon$ is the ratio the molecular weights of water vapor and dry air, equals to 0.622 . Other parameters in the equation are defined above.

2.2.3. Radiation balance at land surface

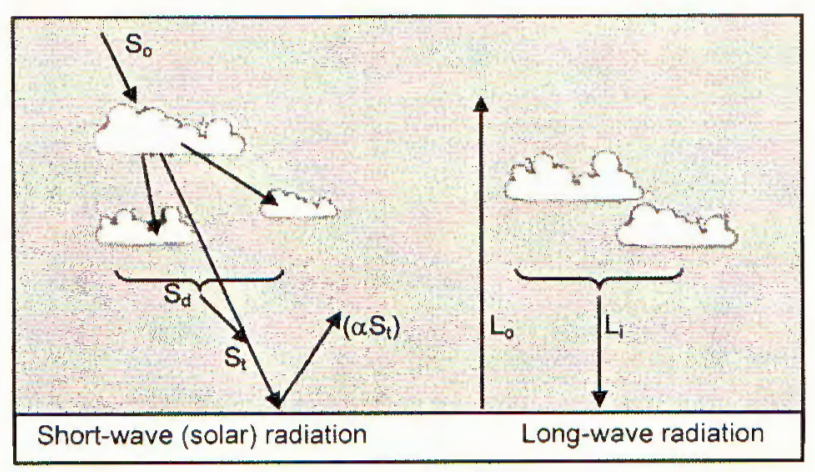

Fig. 1. Radiation balance at the earth's surface

In the absence of restrictions due to water availability at the evaporative surface, the amount of radiant energy captured at the earth's surface is the dominant control on regional evaporation rates. As a monthly average, the radiant energy at the ground may 
be the most "portable" metcorological variable involved in evaporation estimation, in the sense that it is driven by astronomical rather than local climate conditions. Understanding surface radiation balance, and how to quantify it, is therefore crucial to understanding and quantifying evaporation.

\section{a. Net short wave radiation}

The net short wave radiation $S_{n}\left(\mathrm{MJ} \cdot \mathrm{m}^{-2} \cdot \mathrm{day}^{-1}\right)$ is that portion of the incident short wave radiation captured at the ground taking into account losses due to reflection, and given by:

$$
S_{n}=S_{t}(1-\alpha),
$$

where $\alpha$ is the reflection coefficient or albedo; and $S_{t}$ is the solar radiation $\left(\mathrm{MJ} \cdot \mathrm{m}^{-2}\right.$.day $\left.{ }^{-1}\right)$.

The values of albedo for broad land cover classes are given in various scientific literatures. The solar radiation $S_{t}\left(\mathrm{MJ} \cdot \mathrm{m}^{-2}\right.$.day ${ }^{-1}$ ) in most the cases can be estimated (see [6]) from measured sunshine hours according to the following empirical relationship:

$$
S_{t}=\left(a_{s}+b_{s} \frac{n}{N}\right) S_{0},
$$

where $S_{0}$ is the extraterrestrial radiation $\left(\mathrm{MJ} \mathrm{m}^{-2}\right.$.day $\left.{ }^{-1}\right) ; a_{s}$ is the fraction of $S_{0}$ on overcast days $(n=0) ;\left(a_{s}+b_{s}\right)$ is the fraction of $S_{0}$ on clear days (for average climates $a_{s}=$ 0.25 and $\left.b_{s}=0.50\right) ; n$ is the bright sunshine hours per day (h); $N$ is the total day length (h); and $n / N$ is the cloudiness fraction. Valuesfor $N$ and $S_{0}$ for different latitudes are given and tabulated in various handbooks (see [3], [7]).

b. Net long wave radiation

The exchange of long wave radiation $L_{n}\left({\mathrm{MJ} . \mathrm{m}^{-2} \text {.day }}^{-1}\right)$ between vegetation and soil on the one hand, and atmosphere and clouds on the other, can be represented by the following radiation law (see [3], [7], [16]):

$$
L_{n}=\sigma\left(0.9 \frac{n}{N}+0.1\right)\left(0.34-0.14 \sqrt{e_{a}}\right)(T+273)^{4},
$$

where $\sigma$ is the Stefan-Boltzmann constant $\left(4.903 \times 10^{-9} \mathrm{MJ} \cdot \mathrm{m}^{-2} \mathrm{~K}^{-4} \cdot\right.$ day $\left.^{-1}\right)$.

c. Net radiation

The net radiation $R_{n}\left(\mathrm{MJ}_{\mathrm{m}} \mathrm{m}^{-2}\right.$.day $\left.{ }^{-1}\right)$ is the difference between the incoming net short wave radiation $S_{n}$ and the outgoing net long wave radiation $L_{n}$ :

$$
R_{n}=S_{n}-L_{n} .
$$

Using Equation (17) and substituting (16), (18) into (19), for general purposes when only sunshine, temperature, and humidity data are available, Equation (19) can be rewritten as follow:

$$
R_{n}=\left(0.25+0.5 \frac{n}{N}\right) S_{0}-\left(0.9 \frac{n}{N}+0.1\right)\left(0.34-0.14 \sqrt{e_{a}}\right)(T+273)^{4} \sigma .
$$

\section{STUDY AREA AND DATA PROCESSING}

\subsection{Study area description}

The study area $\left(14^{\circ} 41^{\prime}-15^{\circ} 45^{\prime} \mathrm{N}\right.$ and $\left.107^{\circ} 40^{\prime}-108^{\circ} 20^{\prime} \mathrm{E}\right)$ covers $3,160 \mathrm{~km}^{2}$ with the gauging station at Nong Son. It is a mountainous sub-basin of the Vu Gia-Thu Bon basin located in the East of Truong Son mountain range, the center of Vietnam (Fig. 2). The altitude ranges from several meters to 2,550 meters above sea level (data derived from DEM $90 \times 90$ ). The mean slope and the river network density of the basin are $24.2 \%$ and 
$0.41 \mathrm{~km} / \mathrm{km}^{2}$ respectively. The main soil in the basin is granite, alluvial soil, i.e. iron pan, grandiosity, deposit alluvia, clay and sand.

In this study area, there are only four rain gauges in which only one gauge collects hourly data, one climatic station at Tra My, and one discharge gauge at Nong Son. In general, hydro-meteorological station network is poor, i.e. a rain gauge is installed every $800 \mathrm{~km}^{2}$. The data have been provided by the Hydro-Meteorological Data Center (HMDC), the Ministry of Natural Resources and Environment (MONRE) of Vietnam.

Due to the effects of predominating wind direction (North-East in the rainy season) and topography, rainfall in the basin is very high and significantly varies in space and time. According to the rainfall records from 1980 to 2004, the rainfall distribution spatially increases from East to West and from North to South (the mean annual rainfall at Tra My is more than 4,000 mm whereas at Thanh My just more than 2,200 mm).

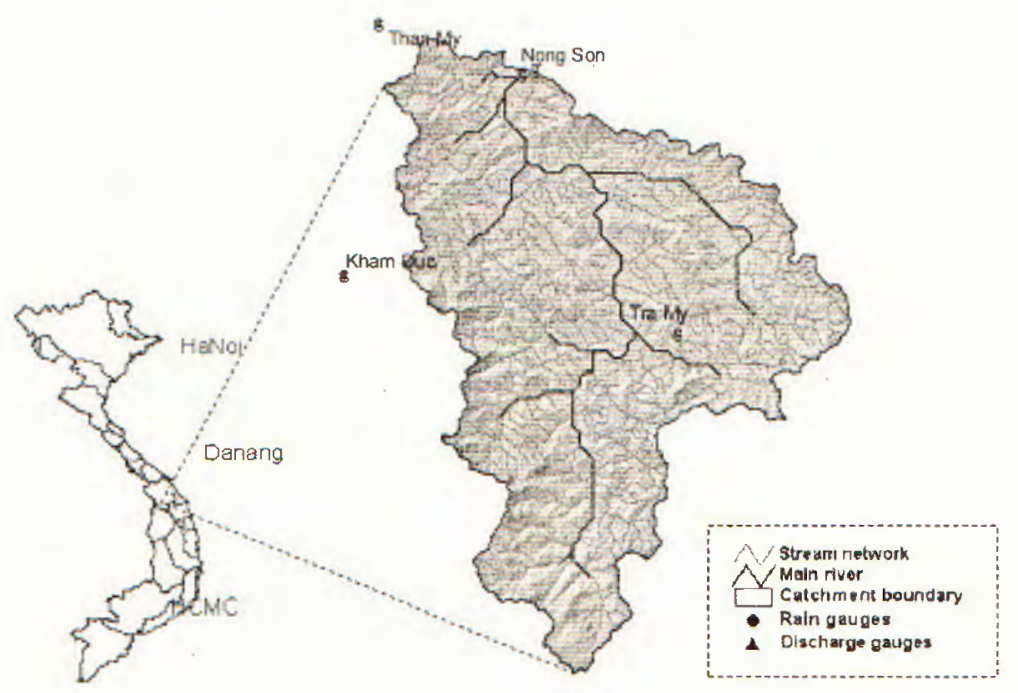

Fig. 2. Nong Son Catchment

For seasonal rainfall distribution, the rainfall in October and November reaches up to $1,800 \mathrm{~mm}$. The period of the North-East wind lasts from September to December coinciding with the rainy season on the basins. Although the rainy season only lasts just for 4 mouths, the rainfall amount occupies $70 \%$ of the annual rainfall. Furthermore, the annual rainfall amounts also show yearly variations from 2,417 $\mathrm{mm}$ (1982). to 6,259 $\mathrm{mm}$ (1996) with an average value of $3,697 \mathrm{~mm}$. The annual runoff coefficient (runoff/precipitation) in this period varies intensively between 0.49 (1982) and 0.81 (1995) with an average value of 0.73 .

\subsection{Land cover data and vegetation-related parameters}

The land cover data was obtained from UMD $1 \mathrm{~km}$ Global Land Cover (http://www.geog.umd.edu/landcover/1km-map.html) based on AVHRR and LDAS (Land Data Assimilation System) information. AVHRR provides information on globe land classification at $30 \mathrm{~s}$ resolution (see [12]). In this study area, there are ten categories of land cover in which evergreen broadleaf occupies a largest area of $48.7 \%$ in total, followed by 
deciduous needleleaf $19.3 \%$, wooded grasslands $18.0 \%$, deciduous broadleaf $4.2 \%$, woodland $3.3 \%$, mixed cover $3.2 \%$, closed shrublands $2.0 \%$, open shrublands $0.6 \%$, grasslands $0.4 \%$, and crop land $0.2 \%$.

For each type of vegetation in the Nong Son catchment, the vegetation parameters such as minimum stomata resistance, leaf-area index, albedo, and zeroplane displacement are derived from http://www.ce.washington.edu/pub/HYDRO/cherkaue/VICNL/Veg/veg_lib; these are as provided in Table 1.

Table 1. Vegetation-related parameters for each type of vegetation in the Nong Son catchment

\begin{tabular}{|l|c|c|c|c|c|}
\hline $\begin{array}{l}\text { Vegetation } \\
\text { classification }\end{array}$ & Albedo & $\begin{array}{c}\text { Minimum stoma } \\
\text { resistance } \\
(\mathrm{s} / \mathrm{m})\end{array}$ & $\begin{array}{c}\text { Leaf area } \\
\text { index }\end{array}$ & $\begin{array}{c}\text { Roughness } \\
\text { length } \\
(\mathrm{m})\end{array}$ & $\begin{array}{c}\text { Zero-plane } \\
\text { Displacement } \\
(\mathrm{m})\end{array}$ \\
\hline Evergreen broadleaf forest & 0.12 & 250 & $3.10-4.40$ & 1.4760 & 8.040 \\
\hline Deciduous needleleaf forest & 0.18 & 125 & $1.52-5.00$ & 1.2300 & 6.700 \\
\hline Deciduous broadleaf forest & 0.18 & 125 & $1.52-5.00$ & 1.2300 & 6.700 \\
\hline Mixed forest & 0.18 & 125 & $1.52-5.00$ & 1.2300 & 6.700 \\
\hline Woodland & 0.18 & 125 & $1.52-5.00$ & 1.2300 & 6.700 \\
\hline Wooded grasslands & 0.19 & 135 & $2.20-3.85$ & 0.4950 & 1.000 \\
\hline Closed shrublands & 0.19 & 135 & $2.20-3.85$ & 0.4950 & 1.000 \\
\hline Open shrublands & 0.19 & 135 & $2.20-3.85$ & 0.4950 & 1.000 \\
\hline Grasslands & 0.20 & 120 & $2.20-3.85$ & 0.0738 & 0.402 \\
\hline Croplands & 0.10 & 120 & $0.02-5.00$ & 0.0060 & 1.005 \\
\hline
\end{tabular}

\subsection{Meteorological data}

In the Penman-Monteith method, meteorological data such as mean temperature, relative humidity, sunshine hour, and wind speed are required. The observed data from the Tra My climatic station for the period of 1980-2004 were used in this study.

- Air temperature $(T)$ : The research basin is located in the monsoon tropical zone. Based on the data at Tra My station, it shows an average annual temperature of $24.5^{\circ} \mathrm{C}$. Average lowest temperature during December-February ranges 20 to $22^{\circ} \mathrm{C}$ with an absolutely minimum of $10.4^{\circ} \mathrm{C}$, and average highest temperature during long period (April to September) ranges 26 to $27^{\circ} \mathrm{C}$ with an absolutely maximum value of $40.5^{\circ} \mathrm{C}$.

- Relative humidity $(R H)$ : The study area lies in a mountainous tropical humidity zone, and as such the value of relative humidity is fairly high and stable with an average value of $87 \%$. The observed data shows that the maximum humidity is in October to December reaching $92 \%$ while the minimum is somewhere between April and July do get as high as $83 \%$ or more.

- Sunshine hours $(n)$ : Because it lies in the high rainy sub-region, sunshine hours in the study area are relatively lower than those in the surrounding areas with a mean annual value of 5.1 hours/day. The monthly average of sunshine hours varies from 2.0 hours/day in December to 7.0 hours/day in May.

- Wind speed and direction $(u)$ : The popular directions of wind are South-East and South-West from May to September, East and North-East from October to April. The wind speed is moderate with an average annual value of $0.9 \mathrm{~m} / \mathrm{s}$. 
Table 2. Monthly average meteorological characteristics in the Nong Son catchment

\begin{tabular}{|l|c|c|c|c|c|c|c|c|c|c|c|c|c|}
\hline Characteristics & Jan & Feb & Mar & Apr & May & Jun & Jul & Aug & Sep & Oct & Nov & Dec & Ave. \\
\hline$T\left({ }^{\circ} \mathrm{C}\right)$ & 20.6 & 21.9 & 24.0 & 26.2 & 26.9 & 27.1 & 27.1 & 26.9 & 25.9 & 24.4 & 22.6 & 20.6 & 24.5 \\
\hline$R H(\%)$ & 89.4 & 87.6 & 84.6 & 82.8 & 84.1 & 83.8 & 83.4 & 84.1 & 87.6 & 90.4 & 92.5 & 92.4 & 86.9 \\
\hline$n$ (hours/day) & 3.5 & 4.7 & 5.9 & 6.5 & 6.9 & 6.6 & 6.7 & 6.3 & 5.2 & 3.9 & 2.6 & 2.0 & 5.1 \\
\hline$u(\mathrm{~m} / \mathrm{s})$ & 0.8 & 1.1 & 1.0 & 0.9 & 0.8 & 0.8 & 0.8 & 0.8 & 0.8 & 0.9 & 0.8 & 0.7 & 0.9 \\
\hline
\end{tabular}

\section{RESULTS AND DISCUSSION}

From the land cover data and vegetation-related parameters in the Nong Son catchment, and the monthly meteorological data at the Tra My climate station in the period of 1980-2004, potential evapotranspiration values were determined by the Penman-Monteith model. Table 3 and Fig. 3 show the results of monthly potential evapotranspiration.

Table 3. Calculated monthly mean potential evapotranspiration for each vegetation type and average over basin in the Nong Son catchment

\begin{tabular}{|l|c|c|c|c|c|c|c|c|c|c|c|c|c|}
\hline ET $(\mathrm{mm})$ & Jan & Feb & Mar & Apr & May & Jun & Jul & Aug & Sep & Oct & Nov & Dec & Annual \\
\hline Evergreen broadleaf & 56 & 63 & 93 & 111 & 123 & 122 & 129 & 123 & 99 & 75 & 54 & 47 & 1,094 \\
\hline Deciduous needleleaf & 53 & 56 & 87 & 124 & 147 & 142 & 149 & 141 & 108 & 84 & 55 & 47 & 1,195 \\
\hline Deciduous broadleaf & 53 & 56 & 87 & 124 & 147 & 142 & 149 & 141 & 108 & 84 & 55 & 47 & 1,195 \\
\hline Mixed cover & 53 & 56 & 87 & 124 & 147 & 142 & 149 & 141 & 108 & 84 & 55 & 47 & 1,195 \\
\hline Woodland & 53 & 56 & 87 & 124 & 147 & 142 & 149 & 141 & 108 & 84 & 55 & 47 & 1,195 \\
\hline Wooded grasslands & 58 & 68 & 108 & 131 & 137 & 130 & 137 & 128 & 106 & 83 & 59 & 49 & 1,194 \\
\hline Closed shrublands & 56 & 66 & 105 & 129 & 135 & 127 & 134 & 126 & 104 & 81 & 57 & 48 & 1,170 \\
\hline Open shrublands & 56 & 66 & 105 & 129 & 135 & 127 & 134 & 126 & 105 & 86 & 62 & 53 & 1,186 \\
\hline Grasslands & 63 & 74 & 108 & 124 & 132 & 125 & 131 & 125 & 105 & 86 & 62 & 53 & 1,188 \\
\hline Crop land & 20 & 9 & 32 & 92 & 123 & 123 & 134 & 132 & 101 & 54 & 22 & 10 & 853 \\
\hline Areal & 56 & 62 & 94 & 119 & 133 & 129 & 136 & 129 & 103 & 79 & 55 & 48 & 1,144 \\
\hline
\end{tabular}

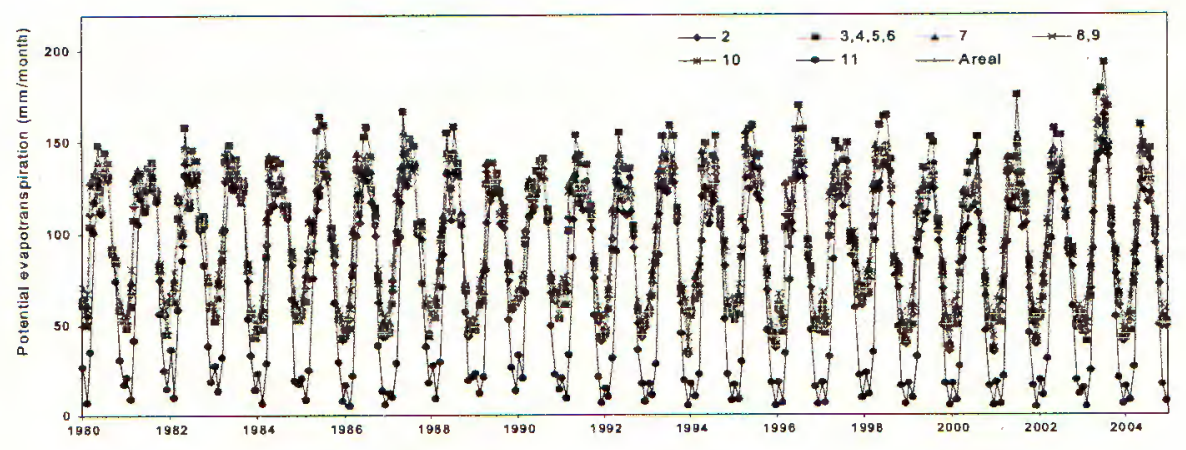

Fig. 3. Calculated $m$ onthly potential evapotranspiration for each type of vegetation and average over basin in the Nong Son catchment in the 1980-2004 period. Note: 2- Evergreen broadleaf; 3, 4, 5, 6- Deciduous needleleaf, Deciduous broadleaf, Mixed cover, and Woodland; 7-Wooded grasslands; 8, 9-Closed shrublands, and Open shrublands; 10- Grasslands; 11- Crop land; and Areal-Average potential evapotranspiration over basin 
Based on the result of Southern Institute of Water Resources Research, the potential evapotranspiration was derived from Piche tube observation values while multiplying it by correction factors, this is usually called $E T_{\text {Piche }}$ (see [27]).

Table 4. Monthly mean potential evapotranspiration estimated by the Penman-

Montheith method and Piche tube data in the Nong Son catchment in the 19802004 period

\begin{tabular}{|l|c|c|c|c|c|c|c|c|c|c|c|c|c|}
\hline$E T(\mathrm{~mm})$ & Jan & Feb & Mar & Apr & May & Jun & Jul & Aug & Sep & Oct & Nov & Dec & Annual \\
\hline$E T_{P-M}$ & 56 & 62 & 94 & 119 & 133 & 129 & 136 & 129 & 103 & 79 & 55 & 48 & 1,144 \\
\hline$E T_{\text {Piche }}$ & 68 & 82 & 118 & 119 & 133 & 120 & 128 & 125 & 103 & 84 & 62 & 56 & 1,198 \\
\hline
\end{tabular}

The comparative performance of $E T$ by the Penman-Monteith method $\left(E T_{P-M}\right)$ and $E T_{\text {Piche }}$ during the 1980-2004 period, Table 4 shows a relatively small difference in the annual value, precisely less than $5 \%$. However there is difference in monthly distribution, particularly from January to March with $E T_{P i c h e}>E T_{P-M}$ of about $27 \%$. Based on the climatic characteristics in Table 2, $E T_{P-M}$ shows a closer accord with the seasonal distribution. Fig. 4 shows that $E T_{\text {Piche }}$ values are somewhat unrealistic, for example, potential evaporation in June 1985 has an average value of $7 \mathrm{~mm} /$ day which is too high for any natural tropical humid area. This result agrees with that of Nguyen (see [22]) that the observed Piche data often give erroneous outputs.

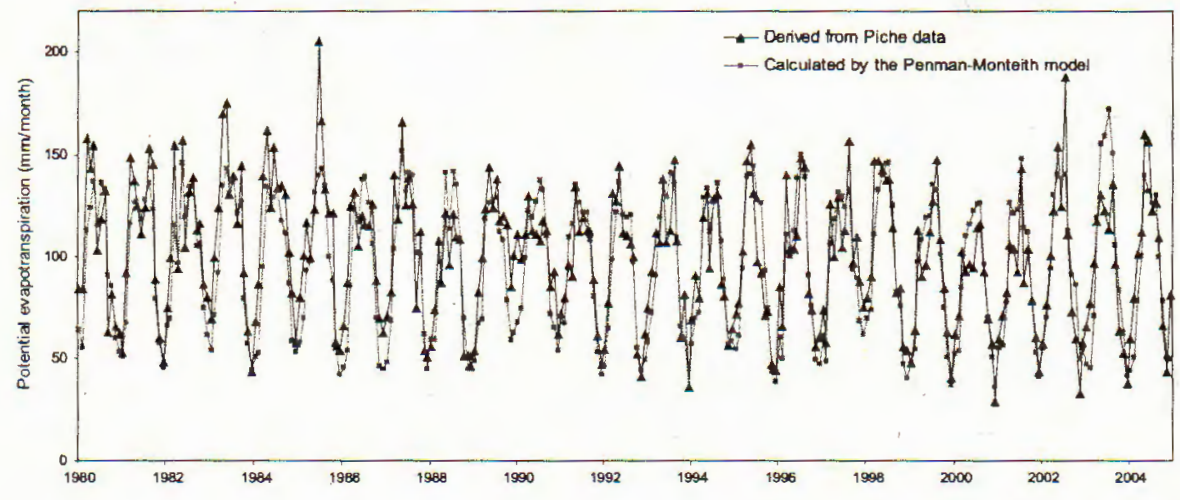

Fig. 4. Comparison of monthly potential evapotranspiration estimated by the Penman-Montheith method and Piche tube data in the 1980-2004 period

In order to assess further the suitability of the potential evapotranspiration estimated directly by the Penman-Monteith method and that derived from the Piche data, the NAM conceptual model was used to simulate the hydrology of the study area in the 1983-2003 period. The NAM model performance is evaluated with a set of two statistical criteria, Bias and Nash-Sutcliffe efficiency cocfficient. (see [21]).

Discharge simulated by using the input data of $E T_{P i c h e}$ and $E T_{P-M}$ is shown in Fig. 5 as monthly averages. Performance measures are given in Table 5 . While the overall simulated discharge with the input of $E T_{P-M}$ is slightly smaller than the observed, in the case of ET Piche it is the reverse. However, the overall water balances (Bias) in both cases are realistic (less than $5 \%$ ). The good thing here is that $E T_{P-M}$ provides a better 
Table 5. Performance measures of two potential evapotranspiration inputs $E T_{P-M}$ and $E T_{P i c h e}$ during the simulation (1983-2003) period for the Nong Son catchment

\begin{tabular}{|l|c|c|}
\hline Performance statistics & $E T_{P-M}$ & $E T_{\text {Piche }}$ \\
\hline Bias (\%) & 3.100 & -2.636 \\
\hline Nash-Sutcliffe efficiency, $R^{2}$ & 0.880 & 0.802 \\
\hline
\end{tabular}

model performance in the term of the Nash-Sutcliffe efficiency (0.880) against that of $E T_{P i c h e}(0.802)$ with respect to the model simulation of the discharge at the stream gauge.

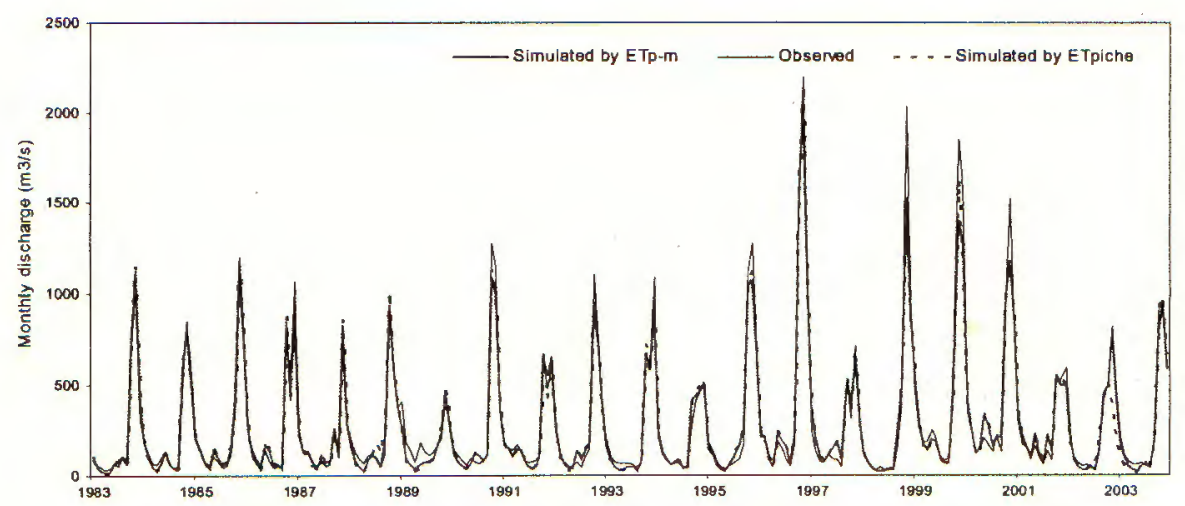

Fig. 5. Observed vs. simulated monthly discharge for the 1983-2003 period using the potential evapotranspiration inputs of $E T_{P i c h e}$ and $E T_{P-M}$

\section{CONCLUSION}

The Penman-Monteith method was used to compute directly the potential evapotranspiration for the Nong Son catchment. The approach was assessed the suitability through the hydrological model response performance. The result of this approach shows a close agreement between the simulated and observed discharges at the stream gauge in comparison with Piche observation. The main conclusion here is that the Penman-Monteith evapotranspiration is more reliable than the Piche method as well as using pan data. Although the approach requires data on land cover and vegetation-related parameters, these data are available in websites in recent years. Hence, due to the importance of evapotranspiration in water balance, the Penman-Monteith method is recommended as the sole standard method to apply for similar catchments.

\section{ACKNOWLEDGEMENTS}

The supports of Danish Hydraulic Institute (DHI) in providing the NAM license for its application and data by Southern Institute of Water Resources are duly acknowledged. We would like to thank the anonymous reviewers and editors for their pertinent comments, leading to improvements in the paper. 


\section{REFERENCES}

1. R.G. Allen, A Penman for all seasons, Jour. of Irr. 6 Drainage Engineering 112 (4) (1987) 348-368.

2. R.G. Allen, Irrigation Engineering Principles, Utah State University, Utah, 1995.

3. R.G. Allen, L.S. Pereira, D. Raes and M. Smith, Crop evapotranspiration-Guidelines for computing crop water requirements - FAO Irrigation and Drainge Paper 56, FAO, Rome, 1998.

4. W. Brutsaert, Comments on surface roughness parameters and the height of dense vegetation, J. Meteorol. Soc. Japan 53 (1975) 96-97.

5. W. Brutsaert, Heat and mass transfer to and from surfaces with dense vegetation or similar permeable roughness, Boundary-Layer Meteorology 16 (1979) 365-388.

6. W. Brutsaert, Evaporation into the atmosphere, D. Reidel Pub. Co., Dordrecht, Holland, 1982.

7. P.J.M. De Laat, and H.H.G. Savenije, Principle of hydrology, Lecture note, IHE, Deft, 2000.

8. DHI Water \& Environment, NAM calculation - DHI materials, Horsholm, Denmark, 2003.

9. DHI Water \& Environment, MIKE 11, Horsholm, Denmark, 2004.

10. C.A. Federer, C.J. Vorosmarty and B. Fekete, Intercomparison of methods for potential evapotranspiration in regional or global water balance models, Water Resour. Res. 32 (1996) 2315-2321.

11. J.R. Garrat and B.B. Hicks, Momentum, heat and water vapour transfer to and from natural and artificial surface, Quarterly Journal of the Royal Meteorological Society 99 (1973) 680-687.

12. M. Hansen, R. Defries, J. R. G. Townshend and R. Sohlberg, Global land cover classification at $1 \mathrm{~km}$ resolution using a decision tree classifier, International J. of Remote Sensing 21 (2000) 1331-1365.

13. P. Trannejad and Y. Shao, Description and validation of the atmosphere-land-surface interaction scheme (ALSIS) with HAPEX and Cabauw data, Global and Planetary Change 19 (1-4) (1998) 87-114.

14. P.G. Jarvis, The interpretation of the variation in leaf water potential and stomatal conductance found in canopies in the field, Philosophical Transactions of the Royal Society of London Series B 273 (1976) 593-610.

15. H. Kirnak and T. H. Short, An Evapotranspiration Model for Nursery Plants Grown in a Lysimeter Under Field Conditions, Turk J Agric For 25 (2001) 57-63.

16. D.R. Maidment, Handbook of hydrology, MacGraw-Hill, New York, 1993.

17. P. Maisongrande, A. Ruimy, G. Dedieu and B. Saugier, Monitoring seasonal and interannual variations of gross primary productivity and net ecosystern productivity using a diagnostic. model and remotely-sensed data, Tellus, 47B, 1985, pp. 178-190.

18. X. Mo, S. Liu, Z. Lin and W. Zhao, Simulating temporal and spatial variation of evapotranspiration over the Lushi basin, Journal of Hydrology 285 (2004) 125-142.

19. J.L. Monteith, Evaporation and Environment, Symp. Soc. Exp. Bio., Cambridge University Press, Cambridge, XIX, 1965, pp. 205-234.

20. J.L. Monteith, Evaporation and surface temperature, Quarterly Joumal of the Royal Meteorological Society 107 (1981) 1-27.

21. J. E. Nash and J. V. Sutcliffe, River flow forecasting through conceptual models, Part I: A discussion of principles, J. Hydrol. 10 (1970) 282-290.

22. Nguyen Ngoc Anh, The Evaluation of Water Resources in the Eastern Nam Bo, Vietnam, Project KC12-05, Southern Institute for Water Resources Planning, Ho Chi Minh City 1995, (in Vietnamese).

23. H. L. Penman, Natural evaporation from open water, bare soil and grass, Proc. Royal Soc. London, A193, 1948, pp. 120-146. 
24. P.J. Sellers, J.A. Berry, G.J. Collatz, C.B. Field, and F.G. Hall, Canopy reflectance, photosynthesis and transpiration, Part III: A re-analysis using improved leaf models and a new canopy integration scheme, Remots Sens. Environ. 42 (1992) 187-216.

25. P.J. Sellers, S.O. Los, C.J. Tucker, C.O. Justice, D.A. Dazlich, G.J. Collatz and D.A. Randall, A revised land surface parameterization (SiB2) for atmospheric GCMs, Part II. The generation of global fields of terrestrial biophysical parameters from satellite data, Journal of Climate $\mathbf{9}$ (1996) 706-737.

26. J.B. Stewart, Modelling surface conductance of pine forest, Agricultural and Forest Meteorology 43 (1988) 19-35.

27. SWECO International, Song Bung 4 hydropower project, TA No. 4625-VIE, Vietnam, 2006.

28. O. Tetens, Uber einige meteorologische, Begriffe. Z. Geophys. 6 (1930) 203-204.

29. C.W. Thornthwaite, An approach toward a rational classification of climate, Geographical Rev. 38 (1948) 55-94.

30. P.J. Vanderkimpen, Estimation of crop evapotranspiration by means of the Penman-Monteith equation, Ph.D. thesis, Utah State University, 1991.

31. D.L. Verseghy, N.A. McFarlance and M. Lazare, CLASS-a Canadian land surface scheme for GCMs, II: Vegetation model and coupled runs, International Joumal of Climatology 13 (1993) $347-370$.

32. C.J. Vorosmarty, C.A. Federer and A.L. Schloss, Potential evaporation functions compared on US watersheds: possible implications for global-scale water balance and terrestrial ecosystem modeling, J. Hydrol. 207 (1998) 147-169.

33. M. C. Zhou, H. Ishidaira, H. P. Hapuarachchi, J. Magome, A. S. Keim and K. Takeuchi, Estimating potential evapotranspiration using the Shuttleworth-Wallace model and NOAAAVHRR NDVI to feed a distributed hydrological modeling over the Mekong River Basin, $J$. Hydrol. $\mathbf{3 2 7}$ (2006) 151-173.

Received March 10, 2008

\section{XÁC ĐỊNH LƯợG BỐC THOÁT HƠ TIỀM NĂNG VÀ ẢNH HƯởNG CỬ NÓ DẾN KẾT QUẢ MÔ HİNH THƯY VĀN}

Lượng bốc thoát hơi tiềm năng có thế tính toán trực tiếp bằng phương trình Penman-Monteith, được biết như là phương pháp một bước. Phương pháp này yêu cầu tài liệu về thảm thực vật và các thông số liên quan dựa vào thông tin AVHRR và LDAS sẵn có những năm gần đây. Tiều vùng Nông Sơn, một phần của lưu vực Vũ Gia-Thu Bồn ở Miền Trung Việt Nam, được chọn cho nghiên cứu này. Mô phỏng quá trình dòng chảy bằng mô hình thuỷ văn (NAM) cho kết quả tốt khi sử dụng giá trị tính toán bốc thoát hơi tiềm năng theo Penman-Monteith. 